\title{
Identifying Engaged Couples' Knowledge and Attitudes about Family Planning
}

\author{
Nişanlı Çiftlerin Aile Planlamasına İlişkkin Bilgi ve Tutumlarının \\ Belirlenmesi
}

\author{
Nevin ÇITAK BILGINN ${ }^{1}$, Bedriye AK ${ }^{2} \oplus$, Dilek COŞKUNER POTUR ${ }^{3} \oplus$, Emine $_{\text {ÖZDOĞAN }}^{4} \odot$

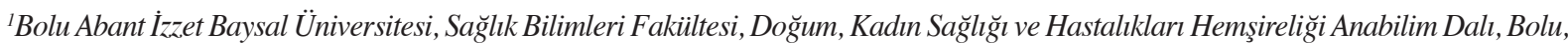 \\ Türkiye \\ ${ }^{2}$ Bolu Abant İzzet Baysal Üniversitesi, Sağlık Bilimleri Fakültesi, Çocuk Sağlığı ve Hastalıkları Hemşireliği Anabilim Dalı, Bolu, \\ Türkiye \\ ${ }^{3}$ Marmara Üniversitesi, Sağllk Bilimleri Fakültesi, Doğum ve Kadın Hastalıkları Hemşireliği Anabilim Dalı, İstanbul, Türkiye \\ ${ }^{4}$ Bolu Il Sağllk Müdürlü̆̆̈̈̈, Bolu, Türkiye
}

\section{ÖZ}

Amaç: Bu çalışma nişanlı çiftlerin aile planlamasına ilişkin bilgi ve tutumlarını belirlemek için yapılmıștır.

Yöntem: Tanımlayıcı ve kesitsel tipteki çalışma, Temmuz, 2013 ve Haziran 2014 tarihleri arasinda Türkiye'nin kuzeyinde yer alan bir ilde, 195 nişanl çift ile yapılmuştır. Verilerin toplanmasinda "Katılımcı Bilgi Formu" ve "Aile Planlaması Tutum Ölçe ği” kullanılmıştır.

Bulgular: Çalışmaya katılan nişanlı çiftlerin yarıdan azı (kadın: \%42,6, erkek \%38,5) aile planlaması yöntemleri hakkında bilgi sahibidir. Erkeklerin bildiği aile planlaması yöntem sayısı $(3,91 \pm 2,73)$, kadinların bildiği yöntem sayısından $(4,57 \pm 2,95)$ daha azdır. Kadinlar tarafindan en fazla bilinen yöntem oral kontraseptif, erkeklerde kondomdur. Kadınlar erkeklere göre aile planlamasına yönelik daha olumlu tutuma sahiptirler $(p<0,05)$. Nişanlı çiftlerin eğitim dïzeyi, alınan aile planlaması bilgisini yeterli bulma, evlendikten sonra yöntem kullanmayı düşünme gibi özelliklerinin aile planlaması tutumunu etkilediği belirlenmiştir $(p<0,05)$.

Sonuç: Nişanlı çiftler genel olarak aile planlamasına yönelik olumlu tutuma sahip olup, kadınların erkeklere göre aile planlaması tutumları daha olumludur.

Anahtar kelimeler: Aile planlamast, tutum, kontrasepsiyon

\section{ABSTRACT}

Objective: This study was conducted to identify engaged couples' knowledge and attitudes about family planning.

Method: This cross-sectional and descriptive study was conducted with 195 engaged couples between July 2013 and June 2014 at a province in Northern Turkey. "Participant Identification Form" and "Family Planning Attitude Scale" were used for data collection.

Results: Less than half of the participating engaged couples (female: $42.6 \%$, male: $38.5 \%$ ), received information about family planning methods. Males knew fewer (3.91 \pm 2.73$)$ contraceptive methods than females (4.57 \pm 2.95$)$. The method mostly known to females was the birth control pill whereas males were most familiar with condoms. As compared to males, females had a more positive attitude towards family planning $(p<0.05)$. The characteristics that were identified as affecting engaged people's attitudes towards family planning included education level, satisfaction with their existing family planning knowledge, and intention to use contraceptive methods after marriage $(p<0.05)$.

Conclusion: Engaged couples generally have positive attitudes towards family planning. Women have a more positive attitude towards family planning than males.

Keywords: Family planning, attitude, contraception

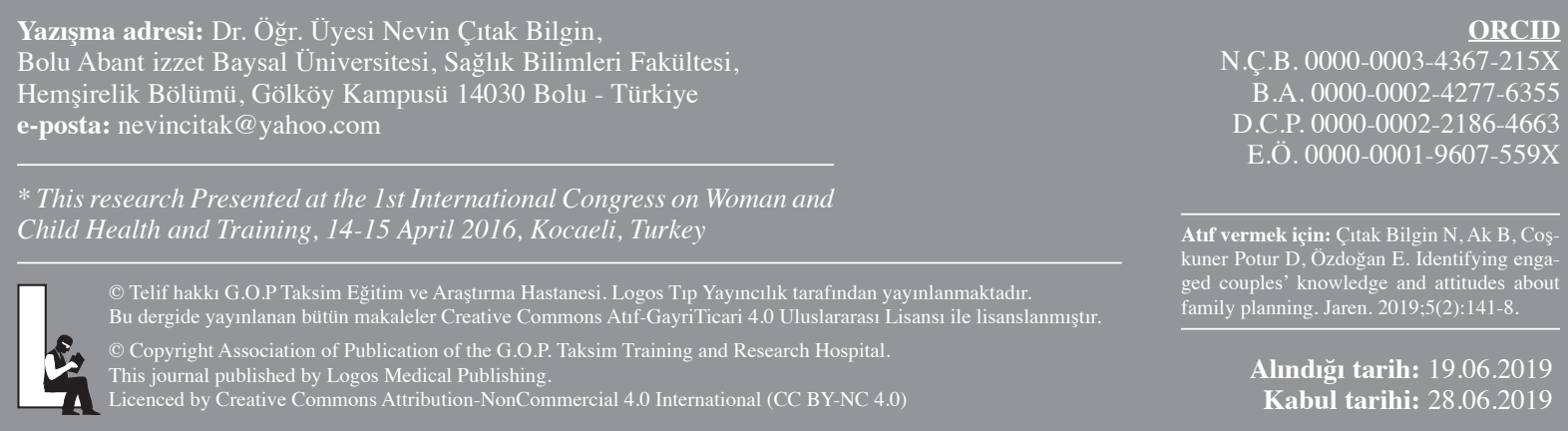




\section{INTRODUCTION}

The use of family planning (FP) methods in developing countries has still not reached the desired levels (1-5). Although legislative regulations that support the implementation of FP services have been in place in Turkey since the 1960s, contraceptive use in this country has still not reached target levels ${ }^{\left({ }^{(}\right)}$. As in many other developing countries, women tend to have more children than they want since their FP needs are not being met ${ }^{(6-9)}$.

According to TDHS, 2013; the rates of modern contraceptive use in Turkey have increased from $31 \%$ in 1988 to $47 \%$ in 2013. Despite this increase, $27 \%$ of women did not use any FP methods, while $26 \%$ of couples still used coitus interruptus ${ }^{(6)}$. According to the studies conducted in different regions of Turkey, the use of modern contraceptive methods ranged from 44 to $68 \%{ }^{(10-12)}$. The studies conducted in some Muslim countries in Africa and Asia showed that rates of modern contraceptive methods ranged from 13 to $37 \%{ }^{(1,3,4,8)}$. Although the use of modern contraceptive methods is higher in Turkey than in other predominantly Muslim developing countries, it is still at a low rate when compared to Western countries ${ }^{(7,13)}$.

Studies have shown that cultural/religious beliefs affect the rates of contraceptive use, as do knowledge, attitudes, and gender-based approaches ${ }^{(3,4,14)}$. The concept of sexuality is generally related to marriage in Muslim countries. So, many of the studies conducted to evaluate knowledge and attitudes about FP in these countries usually focus on married individuals, as well as on women ${ }^{(3,4,9-11,14)}$. However, male attitudes are significant predictors of contraceptive use ${ }^{(15)}$, and ensuring the participation of males in FP planning significantly increases the use of modern FP methods ${ }^{(16)}$.

Given that engaged couples are often young and inexperienced, it is crucial to be aware of the their knowledge and attitudes towards family planning prior to marriage; only then the appropriate FP consultancy services may be provided for them. Furthermore, when their knowledge levels and attitudes are known, male participation in FP services can be ensured, couples will be able to make conscious decisions as to the timing and number of their pregnancies, and FP consultancy services can be continually maintained. An awareness of engaged couples' knowledge and attitudes about FP will also help to decrease the number of unmet needs for FP services while helping couples to improve their reproductive health, with the ultimate goal of realising Turkey's national fertility goals.

\section{METHOD}

\section{Purpose of the Study}

This cross-sectional and descriptive study was conducted to identify engaged couples' knowledge and attitudes about family planning. Answers to following research questions were sought within the framework of the study:

1. Is there a difference in engaged couples' knowledge of FP based on gender?

2. Is there a difference in engaged couples' attitudes towards FP based on gender?

3. Is there a difference in engaged couples' attitudes towards FP based on education level?

4. Is there a difference in engaged couples' attitudes towards FP based on various other parametres (e.g., which partner will select the FP method, partners' opinions about using a contraceptive method after marriage, etc.)?

\section{Study setting and sample}

The study was conducted at the Community Health Center (CHC) in the Bolu Province, the northern part of Turkey where the population's growth rate of $21.9 \%$ is higher than the country average of $13.4 \%{ }^{(17)}$.

This center was chosen because the engaged couples preferred this institution to receive the premarital health report.

The universe of this study was composed of 1673 individuals who applied to the $\mathrm{CHC}$ for premarital health reports before the study was initiated. Based on TDHS data from 2013, the sample size was calculated to be 312 , with a $95 \%$ confidence interval, by taking the rate of modern FP use as $47 \%$, the error rate $(\alpha)$ as $5 \%$, and the study population as 1673 . Previously unmarried couples who applied to the centre were included in the study individually on a voluntary basis. It was decided that data would be 
collected from 450 engaged individuals based on the consideration that one or both of the engaged partners may give incomplete information or leave the study prematurely, thereby making themselves ineligible for inclusion. The study was ultimately completed with 390 individuals (195 couples). Cross- sectional data were collected between July 2013 and June 2014.

\section{Data collection}

To collect data for the study, a Participant Identification Form and the Family Planning Attitude Scale (FPAS) were used. Data were collected with the survey method and the face-to-face interview with each individual separately. The data was confidential from their fiancées.

\section{Instruments}

\section{Participant Identification Form}

The Participant Identification Form, developed by the researchers, includes questions about the sociodemographic characteristics of the couple (i.e. age, gender, level of education) and the couple's FP situation (i.e. methods, FP methods that the couple is aware of, attitudes towards who should decide on the FP method used, thoughts about using FP methods after marriage).

\section{Family Planning Attitude Scale (FPAS)}

The FPAS, developed by Örsal and Kubilay (2007), is a five-point Likert-type scale (i.e. 1=completely agree, $5=$ completely disagree) with 34 items. The scale has three subscales: (1) societal attitudes towards family planning (views about the number of children, male children, and women's roles in society); (2) participants' attitudes towards FP methods; and (3) participants' attitudes towards pregnancy. The lowest and highest scores that can be obtained from the scale are 34 and 170 points, respectively, with higher scores pointing to more positive FP attitudes. The Cronbach Alpha coefficient in Örsal and Kubilay's study was found to be 0.90 (18), while the Cronbach Alpha coefficient in this study was 0.89 .

\section{Data Analysis}

Percentages, means and standard deviation were used as descriptive statistics in the data analysis. Reliability of the FPAS was tested with Cronbach's Alpha coefficients. Normal distribution of the data was evalua- ted with skewness and kurtosis. Since the data did display normal distribution, a student t-test was used for pairwise comparisons, and one-way ANOVA was used for more than two groups. The Tukey test was utilised for the post hoc analysis of multiple comparisons, and the level of statistical significance was set as $\mathrm{p}<0.05$.

\section{Ethical Considerations}

The study was conducted based on the principles of the Helsinki Declaration. Written permissions were obtained from University's Social Sciences Ethics Committee for Human Research (protocol no:2013/05) and the Ministry of Health's Public Health Institution of Turkey (protocol no:2013/66548). Written consent of the couples was taken after providing them with the necessary information about the study. The couples were informed that they could withdraw from the study at any time and also that the data obtained would remain confidential and would not be used anywhere else.

\section{RESULTS}

The participants' socio-demographic characteristics show that the mean age for females in the study was 24.07 (4.13) years and the mean age for males was 26.92 (4.30) years. It was found that $44.6 \%$ of the females and $40.5 \%$ of the males had graduated from college or university. The study showed that $42.6 \%$ of the females and $38.5 \%$ of the males had previously obtained information about FP which was mostly received from health care personnel (females $71 \%$, males $62.7 \%$ ), and $83.1 \%$ of the females and $74.7 \%$ of the males regarded their level of FP knowledge as sufficient. In addition, $88.8 \%$ of the females and $86.7 \%$ of the males were found to believe that couples should decide on FP methods in cooperation.

Table 1 presents male and female participants' views regarding their knowledge of FP methods and their intention to use FP methods. As shown, $79.5 \%$ of the females and $81,0 \%$ of the males stated that they knew about FP methods. The most familiar method to females was the birth control pill, while the least familiar method was female condoms. The most familiar method to males was condoms, while the least familiar method was use of birth control implants. 
Table 1. Engaged People's Views on Their Knowledge on Family Planning Methods and Their Intention to Use Them Based on Gender $(\mathrm{n}=390)$.

\begin{tabular}{|c|c|c|c|c|}
\hline \multirow[b]{2}{*}{ Characteristics } & \multicolumn{2}{|c|}{ Female } & \multicolumn{2}{|c|}{ Male } \\
\hline & $\mathbf{n}$ & $\%$ & $\mathbf{n}$ & $\%$ \\
\hline \multicolumn{5}{|l|}{ Knowledge of contraceptives } \\
\hline Yes & 155 & 79.5 & 158 & 81.0 \\
\hline No & 40 & 20.5 & 37 & 19.0 \\
\hline Number of family planning methods known & \multicolumn{2}{|c|}{$\begin{array}{c}\text { Mean } \pm \text { SD } \\
4.57 \pm 2.95 \\
\text { (range: } 1-12 \text { ) }\end{array}$} & \multicolumn{2}{|c|}{$\begin{array}{c}\text { Mean } \pm \text { SD } \\
4.57 \pm 2.95 \\
\text { (range: } 1-12 \text { ) }\end{array}$} \\
\hline $\begin{array}{l}\text { Known contraceptive methods* } \\
\text { Oral contraceptive pill }\end{array}$ & 124 & 175 & 102 & 165 \\
\hline Condom & 105 & 14.8 & 142 & 22.9 \\
\hline Intrauterine device & 91 & 12.8 & 61 & 9.8 \\
\hline Monthly contraceptive injection & 90 & 12.7 & 58 & 9.4 \\
\hline Withdrawal & 78 & 11.0 & 85 & 13.7 \\
\hline 3 monthly contraceptive injection & 52 & 7.3 & 27 & 4.4 \\
\hline Tubal ligation & 51 & 7.2 & 30 & 4.8 \\
\hline Abstinence & 28 & 3.9 & 23 & 3.7 \\
\hline Implanon & 27 & 3.8 & 15 & 2.4 \\
\hline Vaginal ring & 25 & 3.5 & 20 & 3.2 \\
\hline Vasectomi & 23 & 3.2 & 34 & 5.5 \\
\hline Female condom & 16 & 2.3 & 23 & 3.7 \\
\hline \multicolumn{5}{|l|}{ Intention to use FP methods after marriage } \\
\hline Yes & 106 & 54.4 & 103 & 52.8 \\
\hline No & 89 & 45.6 & 92 & 47.2 \\
\hline Total & 195 & 100.0 & 195 & 100.0 \\
\hline
\end{tabular}

*Numbers do not total 195 as multiple answer were reported

Table 2. Comparison of Family Planning Attitude Scale Mean Scores of Engaged People's Based on Gender (n=390).

\begin{tabular}{|c|c|c|c|c|}
\hline Family planning attitude scale & $\begin{array}{c}\text { Female }(n=195) \\
\text { Mean } \pm \text { SD }\end{array}$ & $\begin{array}{c}\text { Male }(\mathrm{n}=195) \\
\text { Mean } \pm \text { SD }\end{array}$ & $\mathbf{t}^{*}$ & $\mathbf{p}$ \\
\hline Societal attitudes towards family planning & $59.67 \pm 6.96$ & $57.25 \pm 7.23$ & 3.364 & 0.001 \\
\hline Attitudes towards methods & $39.37 \pm 6.61$ & $38.63 \pm 6.24$ & 1.149 & 0.251 \\
\hline Attitudes towards pregnancy & $29.50 \pm 4.73$ & $28.91 \pm 4.32$ & 1.284 & 0.200 \\
\hline FPAS total score & $128.55 \pm 15.22$ & $124.81 \pm 14.27$ & 2.505 & 0.013 \\
\hline
\end{tabular}

SD: Standard deviation * Independent sample t test

Table 2 compares the FPAS subscales and total mean scores based on gender. It was found that the mean scores obtained by females were higher than those of males, and the difference between attitudes of the society towards family planning and the FPAS total mean scores was statistically significant $(\mathrm{p}<0.05)$.

Table 3 displays participants' level of education based on gender and their views about FP as compared to their FPAS mean scores. It was found that FP attitudes differed according to level of education (i.e. university degree, high school degree, primary school) for both genders (females, $\mathrm{p}<0.001$, males, $\mathrm{p}<0.05$ ).

In terms of participants' views on who should decide which FP method to be use, males who stated that males should make this decision had lower mean
FPAS scores, while while male partners who stated that females should make this decision had higher mean FPAS scores wth a statistically significant intergender difference $(\mathrm{p}<0.05)$. What's more, the FPAS mean scores of males who regarded their FP knowledge to be sufficient were found to be higher than those who regarded their FP knowledge to be insufficient $(\mathrm{p}<0.05)$. Women who were considering using the contraceptive method after marriage were found to have a more positive FP attitude than others $(\mathrm{p}<0.01)$.

\section{DISCUSSION}

Having knowledge about FP methods is important for choosing which FP method will be used ${ }^{(11,19)}$. This study found that only $42.6 \%$ of the females and 
Table 3. Comparison of Participants' Level of Education Based on Gender and Their Views About Family Planning with FPAS Mean Scores $(\mathbf{n = 3 9 0 )}$.

\begin{tabular}{|c|c|c|c|c|c|c|c|c|}
\hline \multirow[b]{2}{*}{ Characteristics } & \multicolumn{4}{|c|}{ Female } & \multicolumn{4}{|c|}{ Male } \\
\hline & Mean \pm SD & $\mathbf{F}$ & $\mathbf{p}^{*}$ & $\begin{array}{c}\text { Multiple } \\
\text { comparison }\end{array}$ & Mean \pm SD & $\mathbf{F}$ & $\mathbf{p}^{*}$ & $\begin{array}{c}\text { Multiple } \\
\text { comparison }\end{array}$ \\
\hline \multicolumn{9}{|l|}{ Education level } \\
\hline Primary School (1) & $122.70 \pm 16.20$ & 13.923 & 0.000 & $3>1,2$ & $121.44 \pm 13.63$ & 3.585 & 0.030 & $3>1,2$ \\
\hline High School (2) & $124.62 \pm 12.42$ & & & & $123.18 \pm 14.33$ & & & \\
\hline University (3) & $134.41 \pm 14.65$ & & & & $128.00 \pm 14.00$ & & & \\
\hline \multicolumn{9}{|c|}{ Desicion on FP method } \\
\hline Female (1) & $126.50 \pm 16.20$ & 0.601 & 0.615 & & $128.62 \pm 14.20$ & 2.737 & 0.045 & $1>2$ \\
\hline Male (2) & $119.75 \pm 12.42$ & & & & $111.25 \pm 10.05$ & & & \\
\hline Female \& male (3) & $128.98 \pm 15.17$ & & & & $125.29 \pm 14.15$ & & & \\
\hline \multirow[t]{2}{*}{ Health personnel (4) } & $126.65 \pm 14.65$ & & & & $124.50 \pm 14.27$ & & & \\
\hline & Mean \pm SD & $\mathbf{t}$ & $\mathbf{p}^{* *}$ & & Mean \pm SD & $\mathbf{t}$ & $\mathbf{p}^{* *}$ & \\
\hline \multicolumn{9}{|c|}{ Adequacy of FP knowledge } \\
\hline Sufficient & $131.17 \pm 15.48$ & 1.710 & 0.091 & & $128.91 \pm 13.44$ & 2.590 & 0.012 & \\
\hline Unsufficient & $123.57 \pm 13.37$ & & & & $119.10 \pm 16.50$ & & & \\
\hline \multicolumn{9}{|c|}{ Intention to use FP after marriage } \\
\hline Yes & $131.41 \pm 14.19$ & 2.913 & 0.004 & & $126.51 \pm 14.77$ & 1.769 & 0.078 & \\
\hline No & $125.15 \pm 15.78$ & & & & $122.91 \pm 13.50$ & & & \\
\hline
\end{tabular}

*Numbers do not total 195 as multiple answer were reported

$38.5 \%$ of the males were knowledgeable about FP methods. Other studies in Turkey also showed that neither males nor females had sufficient knowledge on FP methods ${ }^{(10,19,20)}$. Similarly, a study conducted in India showed that only $42 \%$ of the female partners had information on FP methods ${ }^{(2)}$. However, in this study $75.9 \%$ of the females and $81.0 \%$ of the males stated that they knew about FP methods. These results are similar to those obtained in other Muslim countries ${ }^{(3,4,9)}$. This study revealed that on an average the female, and male partners knew 4.6, and 3.9 FP methods, respectively. These results differ from TDHS data ${ }^{(6)}$, which suggest that the average number of 7.6 FP methods are known by female partners.. This result may be due to the fact that the TDHS data also includes married women. However, a study conducted with young people in Australia supports our findings ${ }^{(21)}$.

In the study, the FP methods most familiar to both genders were the birth control pill and condoms, while the least familiar methods were female condoms and implanons. Studies conducted in India and Afghanistan also found that condoms and oral contraceptives to be the most familiar FP methods ${ }^{(5,22)}$. These results also agree with TDHS data ${ }^{(6)}$.

While most engaged individuals were found to have some information about FP methods, almost half of the participants in the study did not intend to use FP methods after marriage. This is not surprising, as national data show that one-fourth of all females without children do not use FP methods ${ }^{(6)}$. Kocaöz et al. ${ }^{(11)}$ identified that $34.6 \%$ of women were not using FP methods before their first pregnancy This lack of contraceptive use during the first years of marriage was associated with the female participants' not regarding pregnancy as an unwanted process. A study conducted in Spain also supports this opinion ${ }^{(13)}$. The current study found that female, and male partners desired to have a mean number of $2.04 \pm 0.65$, and $2.26 \pm 0.83$ children during their reproductive years. This result demonstrates that the male partners wanted to have more children than their female partners a finding that is repeated in other studies ${ }^{(9,23)}$.

Knowledge alone is not sufficient to increase the use of FP methods; attitudes are also significant. Studies have shown that although participants are provided with information about FP, the use of FP methods remains at a low level ${ }^{(2,6,9,23)}$. One study conducted in Nigeria demonstrated that $75 \%$ of female partners knew at least five FP methods, but only $13.1 \%$ of them used contraception ${ }^{(1)}$. Another study conducted mostly on Muslim males and females in Ethiopia, showed that being more knowledgeable about contraceptives was not related to higher rates of contracep- 
tive use ${ }^{(9)}$. In the current study, female partners' mean FPAS scores were higher than males' with a statistically significant intergender difference. This result is similar to the findings obtained by other studies conducted in Australia and Pakistan which showed that women had a more positive attitude towards FP than men ${ }^{(4,21)}$.

The subscale of the FPAS regarding societal attitudes towards family planning has demonstrated that women had a more positive attitude compared to men, with a statistically significant difference between genders The results of a study conducted with married women in Turkey, on societal attitudes towards family planning were similar to the results of our survey ${ }^{(12)}$ but the results obtained in another study contradicts our research findings ${ }^{(14)}$. This difference may be due to the region where the study was conducted. The effects of traditional culture are more pronounced in the rural areas and in the Eastern parts of Turkey, where males are thought to have innate authority over females and where fathering many children is thought to demonstrate male virility ${ }^{(10,18)}$.

Previous studies have shown that attitudes towards family planning are affected by many factors, such as marriage, age, level of education, awareness of FP methods, perceptions of gender, male attitudes, religious beliefs, and a desire to use FP methods $(1,3,9,10,13,24)$. Studies have shown that as the level of education increases, the number of children desired decreases ${ }^{(6)}$ just as increased awareness of FP methods ${ }^{(8,10,25)}$ and positive attitudes towards FP ${ }^{(12,22)}$. Education also protects women from demonstrating passivity and submissive behaviours, and it also enhances their power to make decisions ${ }^{(4,15)}$. The current study found that both males and females with university degrees had a more positive attitude towards FP as compared to participants with an elementary or high school education.

Furthermore, the current study has demonstrated that male and female participants who regarded their knowledge of FP as being sufficient had a more positive attitude towards FP as compared to male and female participants who did not regard their FP knowledge to be sufficient, and this difference was statistically significant in males. It was also found that participants who thought about using FP methods after marriage had a more positive attitude towards FP as compared to others. However, only among women the statistically significant difference existed between thinking about using FP methods and FPAS scores. This finding may be related to feelings of responsibility on the part of the female partners regarding the use of FP methods. While the responsibility in regards to FP should be shared by couples, in general there is a tendency to believe that the methods should be used by female partners ${ }^{(9,26)}$.

This does not mean that decisions in regards to family planning are directly made by females, however especially in rural and traditional communities female empowerment is less common and spouses and other family members can have a say in the matter ${ }^{(2,4,12,15,22,23)}$. One study conducted in Tanzania identified that females with egalitarian gender attitudes were more likely to use contraceptives (24). Indeed, although women in Turkish society often have information about FP methods, it may be considered necessary to receive male approval for contraceptive use due to patriarchal family structures $(18,26)$. The participants who stated that males should make decisions regarding the use of FP methods had more negative attitudes towards FP in general. This result shows that the concept of gender equality in men needs to be improved. Male attitudes are significant predictors of contraceptive use ${ }^{(15)}$ and ensuring the participation of males significantly increases the use of modern FP methods ${ }^{(16)}$. While studies have indicated that males and females alike should take responsibility in regards to the use of FP methods, male participation in FP services was found to be limited and the use of contraceptives was regarded as being the responsibility of female partners $(9,19,22,26)$. Importantly, it has been found that when couples talk about FP issues, the use of FP methods increases ${ }^{(23)}$.

\section{Limitations of the study}

One limitation of this study was that it was conducted in only one province. As regional cultural characteristics may affect attitudes towards FP, future studies might do well to include couples from multiple locations. Furthermore, participants' FP knowledge was assessed based on their statements without using a 
detailed question form about methodology of the study. Future studies may want to utilise a more comprehensive question form. Lastly, this study was conducted prior to marriage, but future studies should be undertaken after marriage as well. Strong aspects of the study include appropriate sample size and participation of both female, and male partners of engaged couples.

\section{CONCLUSION and SUGGESTIONS}

It was identified that engaged couples had insufficient knowledge about FP methods. Females knew more FP methods as compared to males. It was demonstrated that couples' attitudes towards family planning were generally positive (albeit not at desired levels), although females had a more positive attitude compared to males. Attitudes towards FP were affected by higher education levels, the belief that one's FP knowledge was sufficient, and the intention to use FP methods after marriage.

Future studies are needed to define the factors that affect whether couples obtain FP information and what methods they use. It is also suggested that future studies investigate how individuals' negative or positive attitudes affect their use of methods. Gaining awareness of males' knowledge and attitudes about family planning prior to marriage is also crucial in terms of increasing the use of modern contraceptives. Indeed, only by ensuring males' participation in family planning services can national fertility goals be reached. During pre-marriage family planning consultations, health care professionals should ensure the participation of males in the decision-making process. Furthermore, family planning education settings should also be created for unmarried individuals. Also, policies for family planning courses should be developed for use in educational institutions.

\section{Acknowledgments}

We would like to give special thanks to health care personnel in $\mathrm{CHC}$ for their support during the interviews with couples and in data collection. No funding sources have been used for the study.
Ethics Committee Approval: Ethics Committee of Human Research in Social Sciences has been approved by Abant İzzet Baysal University (2013/05).

Conflict of Interest: All authors have no conflict of interest to declare.

Funding: No funding has been used in this study. Informed Consent: Written consent of the couples was taken after providing them with the necessary information about the study.

Etik Kurul Onayı: Abant İzzet Baysal Üniversitesi Sosyal Bilimlerde İnsan Araştırmaları Etik Kurulu onayı alınmıştır (2013/05).

Çıkar Çatışması: Yazarlar arasında çıkar çatışması yoktur.

Finansal Destek: Bu çalışmada hiçbir fon kullanılmamıştır.

Hasta Onamı: Çalışma ile ilgili bilgilendirme yapıldıktan sonra çiftlerden yazılı onam alınmıştır.

\section{REFERENCES}

1. Asekun-Olarinmoye E, Adebimpe W, Bamidele J, Odu O, Asekun-Olarinmoye I, Ojofeitimi E. Barriers to use of modern contraceptives among women in an inner city area of Osogbo metropolis, Osun state, Nigeria. International Journal of Women's Health. 2013;5:647-55. [CrossRef]

2. Chopra S. Dhaliwal L. Knowledge, attitude and practices of contraception in urban population of North India. Arch Gynecol Obstet. 2010;281:273-77. [CrossRef]

3. Mahadeen AI, Khalil AO, Hamdan-Mansour AM, Sato $\mathrm{T}$, Imoto A. Knowledge, attitudes and practices towards family planning among women in the rural southern region of Jordan. Eastern Mediterranean Health Journal. 2012;18(6):567-72. [CrossRef]

4. Mustafa R, Afreen U, Hashmi HA. Contraceptive knowledge, attitude and practice among rural women. J Coll Physicians Surg Pak. 2008;18(9):542-45. [CrossRef]

5. Sherpa SZ, Sheilini M, Nayak A. Knowledge, attitude, practice and preferences of contraceptive methods in Udupi District, Karnata. Journal of Family and Reproductive Health. 2013;7(3):115-20.

6. Turkey Demographic and Health Survey (TDHS-2013) The Hacettepe University, TR Ministry of Health, Ankara. http://www.hips.hacettepe.edu.tr/TDHS_2013_main. report.pdf (accessed August 08, 2016)

7. Darroch JE. Trends in contraceptive use. Contraception. 2013;87(3):259-63. [CrossRef] 
8. Ebrahim SM, Muhammed NK. Knowledge, attitude and practice of family planning among women in Basrah city south of Iraq. The Medical Journal of Basrah University (MJBU). 2011;29(182):70-6. [CrossRef]

9. Tilahun T, Coene G, Luchters S, Kassahun W, Leye E, Temmmerman M, et al. Family planning knowledge, attitude and practice among married couples in Jimma Zone, Ethiopia. Plos One. 2013;8(4):e 61335. [CrossRef]

10. Ayaz S, Efe ŞY. Family planning attitudes of women and affecting factors. Journal of the Turkish German Gynecological Association. 2009;10(3):137-41 .

11. Kocaöz S, Peksoy S, Atabekoğlu CS. The contraceptive methods used before pregnancy and preferred in the postpartum period by women. Balıkesir Health Sciences Journal. 2013;2(1):1-8. [CrossRef]

12. Tezel A, Gönenç IM, Akgün Ş, Karataş DÖ, Yıldız TA. Attitudes towards family planning of women and affecting factors Journal of Anatolia Nursing and Health Sciences. 2015;18:3181-88. [CrossRef]

13. Dueñas JL, Lete I, Bermejo R, Arbat A, Pérez-Campos E, Martínez-Salmeán J, et al. Trends in the use of contraceptive methods and voluntary interruption of pregnancy in the Spanish population during 1997-2007. Contraception. 2011;83:82-7. [CrossRef]

14. Apay SE, Nazik E, Özdemir F, Pasinlioğlu T. The determination of the behaviours about family planning of the women. Journal of Anatolia Nursing and Health Science. 2010;13(3):1-6.

15. Saluja N, Sharma S, Choudhary S, Gaur D, Pandey S. Contraceptive knowledge, attitude and practice among eligible couples of Rural Haryana. The Internet Journal of Health. 2011;12(1):1-6. [CrossRef]

16. Marshall CJ, Gomez AM. Young men's awareness and knowledge of intrauterine devices in the United States. Contraception. 2015;92:494-500. [CrossRef]
17. Turkish Statistical Institute. http://www.tuik.gov.tr/ PreIstatistikTablo.do?istab_id=1591 (accessed August 05, 2016)

18. Örsal, Ö. \& Kubilay, G. Developing family planning attitude scale. Istanbul University Florance Nightingale Journal of Nursing. 2007;15(60):155-64.

19. Altay B, Gönener D. Recognize and utilization of the family planning method among married males and the factors that affect the utilization of these services. Firat Med J. 2009;14(1):56-64.

20. Apay SE, Pasinlioğlu T. Family planning methods engaged-couples thought to use after marriage. Journal of Atatürk University School of Nursing. 2008;11(4):30-7.

21. Ritter T, Dore A, McGeechan K. Contraceptive knowledge and attitudes among 14-24 years old in New South Wales, Australia. Australian and New Zealand Journal of Public Health. 2015;39:267-9. [CrossRef]

22. Dhingra R, Manhas S, Kohli N, Mushtaq A. Attitude of couples towards family planning. Journal of Human Ecology. 2010; 30(1):63-70. [CrossRef]

23. Baldé MD, Diallo BA, Compaoré R, Bah AK, Ali M, Kabra R, et al. Men's behavior surrounding use of contraceptives in Guinea. International Journal of Gynecology \& Obstetrics. 2016;135(1):16-9. [CrossRef]

24. Nanda G, Schuler SR, Lenzi R. The influence of gender attitudes on contraceptive use in Tanzania: New evidence using husbands' and wives' survey data. Journal of Biosocial Science. 2013;45(3):331-44. [CrossRef]

25. Tuladhar H, Marahatta R. Awareness and practice of family planning methods in women attending Gyne OPD at Nepal Medical College Teaching Hospital. Nepal Medical College Journal. 2008;10:184-91.

26. Depe E, Erenel AY. Determination of men's views and behaviours about family planning. Journal of Cumhuriyet University School of Nursing. 2006;10(3):29-36. 